\title{
Biosystematics of the genus Dahlstedtia Malme (Leguminosae, Papilionoideae, Millettieae) ${ }^{1}$
}

\author{
SIMONE P. TEIXEIRA ${ }^{2,4}$ and NEUSA T. RANGA ${ }^{3}$
}

(received: March 13, 2002; accepted: October 23, 2003)

\begin{abstract}
Biosystematics of the genus Dahlstedtia Malme (Leguminosae, Papilionoideae, Millettieae)). Dahlstedtia has been considered a monotypic genus by some authors, but comprising two species according to others. The latter view was supported by our biosystematic study. The two species are Neotropical, mainly occurring in the Brazilian Atlantic Forest, where they are, however, allopatric. Experimental pollinations show that the two species are intersterile. After interspecific crossings, few pollen tubes reach the ovule, a dense secretion fills the micropyle and no proembryos are formed. Probably, there is no gene flow between species, but if it should occur, no hybrids would be formed. The present work confirms Burkart's taxonomic view, according to which Dahlstedtia comprises at least two species: D. pinnata and D. pentaphylla.
\end{abstract}

Key words - allopatry, Dahlstedtia pentaphylla, Dahlstedtia pinnata, gene flow, geographical distribution

RESUMO - (Biossistemática do gênero Dahlstedtia Malme (Leguminosae, Papilionoideae, Millettieae)). O gênero Dahlstedtia, segundo alguns autores, é representado por duas espécies; para outros, é considerado monotípico. Este estudo confirma o primeiro posicionamento. As espécies ocorrem preferencialmente na Floresta Atlântica brasileira: D. pinnata nos estados do RJ e SP e D. pentaphylla em SP, PR e SC, não tendo sido observada sobreposição geográfica. Em polinizações interespecíficas, a fertilização em $D$. pinnata foi evitada pela presença de uma secreção densa na micrópila. $D$. pentaphylla e $D$. pinnata provavelmente não trocam pólen na natureza e, caso ocorresse polinização interespecífica, não haveria formação de sementes. Apesar das semelhanças existentes entre as espécies, confirma-se a posição taxonômica adotada por Burkart, na qual Dahlstedtia é constituído por pelo menos duas espécies: $D$. pinnata e $D$. pentaphylla.

Palavras-chave - alopatria, Dahlstedtia pentaphylla, Dahlstedtia pinnata, distribuição geográfica, fluxo gênico

\section{Introduction}

The genus Dahlstedtia Malme belongs to the Leguminosae, subfamily Papilionoideae, tribe Millettieae (Geesink 1984), with two described species: D. pinnata (Benth.) Malme (type species) and D. pentaphylla (Taub.) Burkart. Species descriptions are confused with regard to floral morphology and even Burkart (1957), who recognized them as two distinct species, cited specimens of one taxon under the second one. As Dahlstedtia species present low fruit and seed set, collections with fruiting specimens are sparse, especially for $D$. pinnata (only four fruiting specimens were observed in this study). As a consequence, the genus was only established in 1905, when the fruit was seen

\footnotetext{
1. This work is a part of a PhD thesis developed at the Department of Botany, Universidade Estadual de Campinas, Campinas/SP.

2. Universidade de São Paulo, Departamento de Ciências Farmacêuticas, Av. do Café, s/n, 14040-903 Ribeirão Preto, SP, Brazil.

3. Universidade Estadual Paulista, Departamento de Botânica, 15054-000 São José do Rio Preto, SP, Brazil, neusatr@bot.ibilce.unesp.br

4. Corresponding author: spadua@fcfrp.usp.br
}

for the first time by Malme in Stockholm (Malme 1905). Bentham (1862) had previously had problems with D. pinnata, which he treated as "?Camptosema ?pinnatum". Similarly, D. pentaphylla, despite its description by Taubert (1889) as "Camptosema ?pentaphyllum", was only transferred to Dahlstedtia in 1957 when Burkart could verify the fruit morphology (Burkart 1957). Despite other morphological differences between species of Camptosema and the species included nowadays in Dahlstedtia, the indehiscent fruit of Dahlstedtia was one of the essential characters used in the generic circumscription by Malme (1905).

Since the establishment of the genus by Malme in 1905, no taxonomic revision has been undertaken with Dahlstedtia, although Hutchinson (1964), Geesink (1981) and Vanni \& Rodríguez (1999) considered Dahlstedtia as a monotypic genus, including only $D$. pinnata. Teixeira \& Gabrielli (2000) studied stem and root anatomy of the described Dahlstedtia species to search of helpful characters for taxa delimitation. Most of the distinctive characters found in the vegetative axis are quantitative and need to be utilized with caution. However, the difference in the origin of secretory cavities in the shoot apex was considered a good character in species distinction by those authors. 
Representatives of Dahlstedtia are shrubs or trees, with conspicuous papilionate flowers. They have been registered from Brazil, especially in the Atlantic Forest (Geesink 1981), but the full distribution have never been established. Phytosociological studies from the Northeastern Atlantic Forest in São Paulo State (Picinguaba and Ubatuba) revealed a low density of $D$. pinnata, suggesting that it is a rare species (A. Takahasi, unpublished data).

Based on descriptions of Malme (1905) and Burkart (1957) and on additional morphological characters observed at the field it is possible to distinguish two morphs of Dahlstedtia: (1) plants with pendant inflorescence, flowers with geranium-red corolla, and conspicuous lenticels on the floral branches, described as D. pentaphylla (Taub.) Burkart; (2) and plants with erect inflorescence, flowers with purple corolla, and inconspicuous lenticels on the floral branches, as D. pinnata (Benth.) Malme.

The aim of the present work was to determine whether recognition of two species based on these characters can be justified. The following questions were addressed: Are there in fact two species, and if so are their distributions sympatric or allopatric? And if allopatric, are there any ecological factors favoring disjunction? Is there any overlap in their flowering and fruiting periods? And are they intersterile?

\section{Material and methods}

Material allegedly of Dahlstedtia pentaphylla and D. pinnata was collected from cultivated plants in Campinas, São Paulo State, Brazil. Field collections of D. pinnata were gathered from natural populations at Parque Estadual da Serra do Mar, comprising the areas of Picinguaba, Ubatuba and Caraguatatuba, São Paulo State, Brazil and of D. pentaphylla at Parque Estadual de Intervales, located at Capão Bonito, São Paulo State, Brazil. The vouchers are deposited in the Herbarium of Universidade Estadual de Campinas (UEC), São Paulo State, Brazil.

In addition, specimens of Dahlstedtia were studied in the following herbaria: HB, MBM, R, RB, SP, SPSF, UEC and UPCB. All label information was recorded.

Geographical distribution - Geographical coordinates of the localities were used to elaborate a map using VersaMap 2.07 Shareware software (http://www.versamap.com). Locality altitudes were plotted in a box-plot for both species utilizing Systat 9 (C) SpSS Inc.).

Flowering and fruiting - Herbarium label informations and field observations were utilized for establishing the flowering and fruiting periods.

Experimental pollinations between morphological species -
Cultivated plants from Campinas (D. pinnata and D. pentaphylla) and Piracicaba (D. pentaphylla), and of natural populations from Ribeirão Grande (D. pentaphylla) and Ubatuba ( $D$. pinnata) were utilized in the experimental pollinations between specimens.

Pollen germination on the stigma, pollen tube growth and fertilization events were studied after manual interspecific pollinations. The number of flowers per treatment was at least 10. Hand pollinated pistils were collected $6,12,24,48,72,96$, 120 and $144 \mathrm{~h}$ after pollination. Features of pollen tube growth in the stigma and style were investigated using fluorescence microscopy after clearing of the pistils in $\mathrm{NaOH}$ and staining in Aniline Blue (Martin 1959). Serial sections were made after fixation of the material in Karnovsky solution for $24 \mathrm{~h}$ (Karnovsky 1965), gradual dehydration in an alcohol series and embedding in paraplast (Prakash 1986). The section thickness varied from 5 to $8 \mu \mathrm{m}$. Sections were stained with Safranin-Fast Green (Prakash 1986) and permanent slides were mounted in Epoxi resin. As control procedures, these results were compared to those of self- and cross-pollination/ fertilization in the same plants of $D$. pentaphylla and D. pinnata, published by Teixeira et al. (2001).

Data analysis - Relationship between specimens occurrence and their geographical variables (latitude, longitude, and altitude) was analyzed by logistic regression (Hosmer \& Lemeshow 1989) in Systat 9, utilizing as observation each locality where specimens occur. As the two specimens are not sympatric, data of presence and absence for them are complementary, revealing opposing information. Therefore, in logistic regression data of presence and absence of only one arbitrarily chosen specimen (dependent-variable), D. pentaphylla, were utilized against geographical data (independent-variables).

\section{Results}

Using the morphological criteria noted above, the herbarium collections studied were distinguished as follows:

Dahlstedtia pinnata (Benth.) Malme

BRAZIL: Rio DE JANEIRO: Barra Mansa, s.d. (fl., fr.), O. Yano 1320 (SP); Campo Grande, 13-I-1950 (fl.), L.R. Mello Filho 1011 (R); Campo Grande, 4-IV-1978 (fr.), G. Martinelli 4173 (RB); Ibiapus, XI1921 (fl.), G. Setslt 233 (RB); Magé, 6-XII-1984 (fl.), G. Martinelli 10589 (MBM); Magé, 4-IV-1989 (fl.), C. Giordano 614 (RB); Petrópolis, II-1917 (fl.), C. Diogo 901 (R); Petrópolis, 15-XII-1932 (fl.), E. Viana s.n. (RB610033); Rio Bonito, 27-XI-1972 (fl.), P. Laclette 205 (R); Rio Bonito, 26-X-1975 (fl.), P. Laclette 265 (R); Rio de Janeiro, 19-XII-1868 (fl.), A. Burkart s.n. (R8633); Rio de Janeiro, 13-I-1883 (fl.), 
s. col. (R 69092); Rio de Janeiro, 12-XII-1891 (fl.), E. Ule 2378 (R); Rio de Janeiro, 4-VI-1913 (fl.), F. Tamandaré \& A.C. Brade 6405 (SP); Rio de Janeiro, I-1917 (fl.), F.C. Hoehne 119 (SP); Rio de Janeiro, 24-II-1917 (fl.), C. Diogo s.n. (R 64706); Rio de Janeiro, 1924 (fr.), D. Castanheiro s.n. (RB19113); Rio de Janeiro, 26-II-1926 (fl.), pessoal do Horto Florestal s.n. (RB61034); Rio de Janeiro, 21-I-1929 (fl.), C. Porto 1881 (RB); Rio de Janeiro, 19-XII-1933 (fl.), Freire s.n. (R67599); Rio de Janeiro, 10-VIII-1940 (fl.), W.D. Barros 16 (RB); Rio de Janeiro, 6-II-1946 (fl.), Altamiro 25 (RB); Rio de Janeiro, 10-XI-1946 (fl.), J.N. Vieira s.n. (RB57826); Rio de Janeiro, 19-XII-1946 (fl.), L.E. Mello Filho 533 (R); Rio de Janeiro, 3-II-1960 (fl.), H.F. Martins s.n. (RB 170033); Rio de Janeiro, 25-II-1967 (fl.), D. Sucre 1946 (RB); Rio de Janeiro, 23-I-1968 (fl.), D. Sucre 2142 (RB); Rio de Janeiro, 5-II-1971 (fl.), M.C. Valente s.n. (RB146675); Rio de Janeiro, 16-III-1972 (fl.), J. Almeida \& R. Laroche 1371 (RB); Rio de Janeiro, 25-X-1988 (fl.), R. Marquete 157 (RB); Teresópolis, 1-III-1969 (fr.), P.I.S. Braga 1536 (RB). São PAULO: Biritiba Mirim, 30-III-1983 (fl.), A. Custodio Filho 2128 (SP); Biritiba Mirim, 29-IX-1983 (fr.), A. Custodio Filho 1583 (SP); Biritiba Mirim, 28-XII-1983 (fl.), A. Custodio Filho \& T.M. Cerati 1258 (SP); Biritiba Mirim, 3-II-1984 (fl.), A. Custodio Filho 2240 (SP); Caraguatatuba, 5-II-1993 (fl.), S. Buzato \& M. Sazima 28007 (UEC); Iguape, XII-1921 (fl.), A.C. Brade 8204 (R); Queluz, 7-IV-1995 (fl.), J.L.A. Moreira $42 \&$ R. Belinelo (UEC); São José do Barreiro, 30-XI-1999 (fl.), L. Freitas 786 (UEC); São Sebastião, 27-XII-1972 (fl.), J. Mattos 15665 \& N. Mattos (SP); São Sebastião, 6-X-1979 (fl.), G. Shepherd et al. 10450 (UEC); São Sebastião, 23-VIII-1983 (fl.), J.R. Pirani \& O. Yano 749 (SP); São Sebastião, 10-XI-1990 (fl.), L.P. Queiroz 2767 (MBM); Serra da Bocaina, I-1925 (fl.), A. Lutz \& B. Lutz 1731 (R); Ubatuba, 11-X-1937 (fl.), R.D. Gonçalves s.n. (SP38756); Ubatuba, 7-XI-1961 (fl.), J. Fontella \& C. Moura 103 (SP); Ubatuba, 9-XI-1976 (f1.), P.E. Gibbs et al. 3490 (UEC); Ubatuba, 25-X-1979 (fl.), W. Mantovani 167 (SP); Ubatuba, 10-XI-1993 (fl.), M.T.Z. Toniato s.n. (UEC30151); Ubatuba, 27-XII-1993 (fl.), B.B. Klitgaard s.n. (RB 306298).

\section{D. pentaphylla (Taub.) Burkart}

BRAZIL: PARANÁ: Antonina, 14-XII-1871 (fl.), Schwacke 2650 (RB); Antonina, 20-VII-1972 (fl.), s. col. (MBM23096); Antonina, s.d. (fl.), G. Hatschbach s.n. (MBM88524); Antonina, 29-VIII-1972 (fr.), G. Hatschbach 30276 (MBM); Antonina, 7-XI-1986 (fl.), A.C. Cervi 2398 (UPCB); Antonina, 14-IX-1987 (fl.), A.C. Cervi 2458 (UPCB); Bocaiúva do Sul, 24-III-1970 (fl.), G. Hatschbach 24043 (MBM); Campo Grande do Sul, 6-X-1967 (fl.), G. Hatschbach 17344 (MBM); Campo Grande do Sul, 7-IX-1996 (fr.), J.M. Silva 1717 (MBM); Cêrro Azul, 17-VIII-1966 (fl.), J. Lindeman \& H. Haas 2358 (MBM); Cêrro Azul, 8-XII-1994 (fl.), G. Hatschbach 61466 (MBM); Guaraqueçaba, 14-XII-1967 (fr.), G. Hatschbach 18132 (MBM); Guaraqueçaba, 19-III-1989 (fl.), M.L. Sekiama 52206 (UEC); Guaraqueçaba, 20-I-1993 (fl., fr.), J. Prado 440 (MBM); Guaraqueçaba, 15-XI-1993 (fl.), R.X. Lima 125 (UPCB); Guaraqueçaba, 28-X-1994 (fl.), S.F. Athayde 122 (UPCB); Guaraqueçaba, 19-XI-1995 (fl.), R.X. Lima 180 (UPCB); Guaratuba, 7-XII-1971 (fl.), P.I.S. Braga 2311 \& M. Braga (RB); Guaratuba, 18-I-1986 (fl.), A. Krapovickas \& C.L. Cristóbal 40332 (MBM); Guaratuba, s.d. (fl.), G. Hatschbach 29341 \& O. Guimarães (MBM); Guaruvá, 6-II-1957 (fl.), G. Hatschbach 3600 (MBM); Ilha de Currais, 4-II-1997 (fl.), C. Jaster s.n. (UPCB29624); Ipiranga, II-1904 (fl., fr.), P. Dusén 3787 (R); Matinhos, 1-II-1974 (fl.), R. Kummrow 284 (MBM); Matinhos, 20-V-1975 (fl.), M.T. Shirata 155 \& J.A. Cunha (UPCB); Matinhos, 10-XII-1985 (fl.), M.T. Shirata 253 (UPCB); Matinhos, 12-IV-1986 (fl.), S.M. Silva s.n. (UPCB 19752); Morretes, 4-I-1966 (fl.), G. Hatschbach 13413 (MBM); Morretes, 8-VIII-1968 (fl.), G. Hatschbach 19580 (MBM); Morretes, 20-X-1977 (fl.), G. Hatschbach 40005 \& L. Landrum (MBM); Morretes, 28-XII-1977 (fl.), G. Hatschbach 40647 \& R. Kummrow (MBM); Morretes, 7-XII-1979 (fl.), G. Hatschbach 42612 (MBM); Morretes, 5-II-1983 (fl.), G. Hatschbach 46102, H.C. Lima \& S. Mayo (MBM); Morretes, 30-X-1984, F.C. Silva s.n. (UPCB); Morretes, 30-V-1985 (fl.), P.I. Oliveira 916 \& J. Cordeiro (MBM); Morretes, 8-I-1986 (fl.), R. Kummrow 2723 (MBM); Morretes, 9-V-1986 (fl.), A.C. Cervi \& Acra 2362 (UPCB); Morretes, 3-VIII-1995 (fr.), J.M. Silva 1491 \& E.P. Santos (MBM); Paranaguá, 28-V-1968 (fr.), G. Hatschbach 19253 (MBM); Paranaguá, 10-III-1985 (fl.), R.M. Britez \& S.M. Silva s.n. (UPCB19841); Paranaguá, 8-XI-1986 (fl.), R.M. Britez 1089 \& S.M. Silva 910 (UPCB); Paranaguá, 10-XI-1986 (fl.), S.M. Silva 931 \& W.S. Souza (UPCB); Paranaguá, 5-XII-1986 (fl.), E.B. Schwarz 127 (UPCB); Pinhão, 25-X-1991 (fl.), F. Bonato \& H.R.S. Abrão 12 (MBM); Piraquara, 21-V-1974 (fl.), G. Hatschbach 34439 \& R. Kummrow 
(MBM); Piraquara, 4-XI-1982 (fl.), R. Kummrow 2069 (MBM); Porto Vitória, 8-XII-1971 (fl.), G. Hatschbach 28421 (MBM); Quatro Barras, 12-IV-1988 (fl.), J.M. Silva 488 \& J. Cordeiro (MBM); Rio Branco do Sul, 7-V-1968 (fl.), G. Hatschbach 19193 (MBM); Serra da Graciosa, 30-XI-1982 (fl.), A.C. Cervi 2095 \& J. Casas (UPCB); Serra da Graciosa, 17-IV-1996 (fl.), S.F.B. Luz s.n. (UPCB28450). Santa Catarina: Blumenau, 14-IX-1950 (fl.), J.G. Kuhlmann s.n. (RB72795); Enseada de Brito, VIII-1946 (fl.), B. Carris s.n. (RB57454); Florianópolis, 19-XII-1968 (fl.), R.M. Klein \& Bresolin 8058 (MBM); Itajaí, 22-III-1956 (fl.), R. Reitz \& R.M. Klein 2878 (MBM); Itajaí, 21-VI-1956 (fl.), R. Reitz \& R.M. Klein 3364 (MBM); Itapacá, 5-IX-1897 (fr.), Schwacke s.n. (RB 38065); Itapiranga, 18-X-1964 (fl.), L.B. Smith \& R. Reitz 12684 (R). SÃo Paulo: Arujá, 12-VII-1971 (fl.), A. Custodio Filho 649 (SP); Arujá, 12-VII-1981 (fl.), A. Custodio Filho 629 (SP); Bom Sucesso, 21-X-1966 (fl.), J. Mattos 14075 (SP); Cananéia, 15-III-1976 (fl.), M.C. Marino s.n. (SP137781); Cananéia, IX-1976 (fl.), M. Sakane 564 (SP); Cananéia, 10-XI-1977 (fl.), D.A. De Grande 17 (UEC); Cananéia, 9-X-1980 (fl.), F. Barros 494 (UEC); Cubatão, 13-XII-1988 (fl.), M. Kirizawa \& E.A. Lopes 2125 (SP); Eldorado, 17-V-1994 (fr.), I. Cordeiro \& M.A.B. Barros 1406 (UEC); Eldorado, 9-II-1995 (fl.), L. Sakai s.n. (UEC32707); Eldorado, 14-V-1996 (fl.), J.A. Pastore \& F.A.R.D.P. Arzolla 710 (SPSF); Igaratá, 3-VIII-1949 (fl.), M. Kuhlmann 1945 (SP); Iguape, 17-XI-1982 (fl.), N.S. Figueiredo \& R.R. Rodrigues 14713 (UEC); Iguape, 12-I-1985 (fl.), N.S. Figueiredo \& U.S. Dias 16758 (UEC); Ilha do Cardoso, 11-I-1977 (fl.), G.J. Shepherd \& D.M. Vital 11218 (UEC); Ilha do Cardoso, 5-VIII-1977 (fl.), P.E. Gibbs \& H.F. Leitão Filho 5631 (UEC); Ilha do Cardoso, 14-XII-1984 (fl.), H.F. Leitão Filho 10804 (UEC); Iporanga, 15-V-1996 (fl.), G.A.D.C. Franco \& F.A.R.D.P. Arzolla 1412 (SPSF); Itapevi, 14-IV-1977 (fl.), M. Sakane 532 (MBM); Joanópolis, 16-VIII-1994 (fl.), J.Y. Tamashiro 503 (UEC); Juquiá, 29-IX-1977 (fl., fr.), P.E. Gibbs et al. 6664 (UEC); Miracatu, s.d. (fl.), P. Martuscelli 164 (SP); Mogi das Cruzes, 18-IV-1921 (fl.), A. Gerht 5503 (SP); Mogi das Cruzes, 17-I-1941 (fl.), N.V. Guaximbú 5181 (SP); Monteiro Lobato, 29-IX-1976 (fl.), P.H. Davis 2934 (UEC); Monteiro Lobato, 22-X-1988 (fl.), s. col. (SP254800); Paiol do Meio, 13-X-1940 (fl.), F.C. Hoehne s.n. (SP44422); Paiol do Meio, 15-X-1940 (fl.), A. Gerht 44422 (SP); Paranapiacaba, 21-VI-1991 (fl.), $S$. Ferreira s.n. (SP256572); Piracicaba, 20-IX-1991 (fl.), R.B. Martins s.n.(UEC 89593); Piracicaba, 1-VII-1993 (f1.), K.D. Barreto s.n. (UEC 89470); Piracicaba, 17-V-1994 (fr.), N.M. Ivanauskas 83 (UEC); Ribeirão Grande, 4-VIII-1994 (fl.), s. col. (UEC79285); Ribeirão Grande, s.d. (fl.), S.P. Teixeira s.n. (UEC109267); Salesópolis, 28-I-1949 (fl.), E. Kuehn \& M. Kuhlmann 1766 (SP); Santa Branca, 30-VII-1988 (fl.), s. col. (SP254805); Santa Isabel, 14-VIII-1936 (fl.), $M$. Kuhlmann s.n. (SP35811); Santo André, 16-XII-1991 (fl.), S.J.G. Silva 282 (RB); São José dos Campos, 25-VIII-1967 (fl.), J. Mattos 15057 \& N. Mattos (SP); São Paulo, 14-XI-1933 (fl.), V. Carneiro s.n. (SP31185); São Paulo, s.d. (fl., fr.), M.E. Koscinski 353 (SP); São Vicente, 30-VIII-1991, F.S. Santos (UEC68729).

Geographical distribution - According to field observations, informations on herbarium labels and in literature, Dahlstedtia species occur mainly in the Brazilian Atlantic forest, in areas of the Atlantic Plateau and the "Costeira" Prairie. There is one bibliographic record of $D$. pentaphylla in Northeastern Argentina. D. pinnata is found in Rio de Janeiro and São Paulo States, and D. pentaphylla in São Paulo, Paraná and

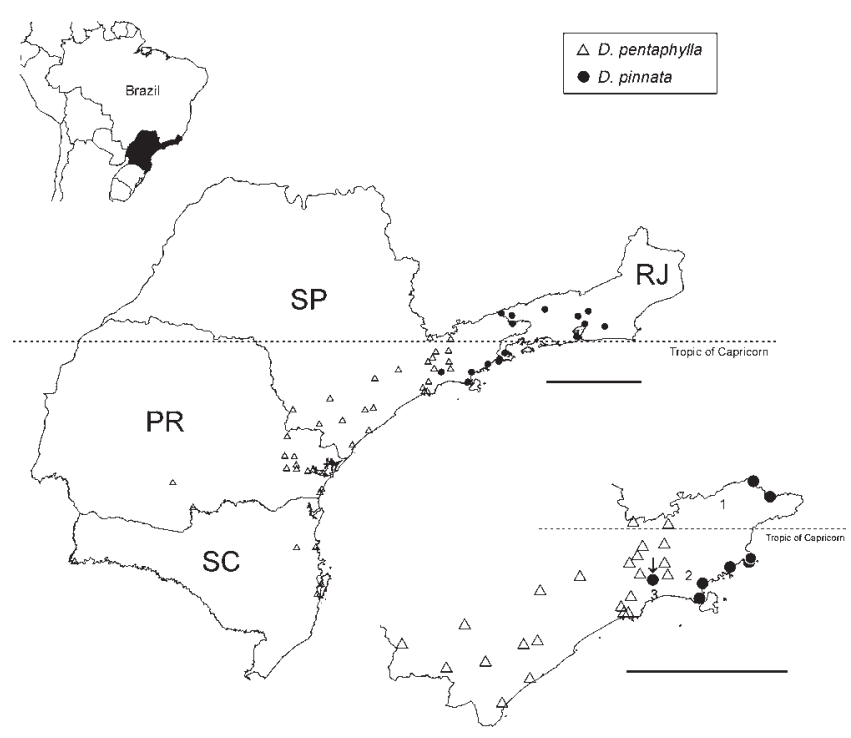

Figure 1. Geographical distribution of Dahlstedtia in Brazil and in São Paulo State. Brazil map: RJ = Rio de Janeiro State, $\mathrm{SP}=$ São Paulo State, $\mathrm{PR}=$ Paraná State, $\mathrm{SC}=$ Santa Catarina State. São Paulo State map: Numbers represent geographical landscapes that probably isolate Dahlstedtia species in São Paulo State. 1 = "Campos do Jordão" Plateau and "Médio Vale do Paraíba" Hills; 2 = "Natividade-Quebra-Cangalha" Mountain Range ("Paraitinga" Plateau); 3 = "Juqueriquerê" Plateau. The arrow indicates the occurence of $D$. pinnata at "Estação Biológica de Boracéia", Biritiba-Mirim. Scale bars $=200 \mathrm{~km}$. 
Santa Catarina States, without geographical superposition of the specimens (figure 1). Only in São Paulo State there are registrations for close occurrence of the two species (figure 1), but the localities are separated by topographic features as follows (figure 1): (1) between Queluz (D. pinnata) and Monteiro Lobato (D. pentaphylla): towns separated by the "Campos do Jordão" Plateau and by the "Médio Vale do Paraíba" Hills; (2) between Caraguatatuba (D. pinnata) and Salesópolis (D. pentaphylla): towns separated by the "Natividade-Quebra-Cangalha" Mountain Range ("Paraitinga" Plateau); (3) between São Sebastião (D. pinnata) and São Vicente (D. pentaphylla): towns separated by the "Juqueriquerê" Plateau. Moreover, there is a record of $D$. pinnata at "Estação Biológica de Boracéia" in Biritiba-Mirim, between two localities (Salesópolis and Moji das Cruzes) where D. pentaphylla occurs (figure 1, arrow). Biritiba-Mirim is $21 \mathrm{~km}$ far away from Moji das Cruzes and $24 \mathrm{~km}$ from Salesópolis.

Individuals of $D$. pinnata occur in altitudes ranging from $2.30 \mathrm{~m}$ (Rio de Janeiro, Rio de Janeiro State) to 870 m (Teresópolis, Rio de Janeiro State); individuals of $D$. pentaphylla are found in altitudes ranging from $1.60 \mathrm{~m}$ (Itajaí, Santa Catarina State) to $1,053 \mathrm{~m}$ (Rio Branco do Sul, Paraná State) (figure 2). Individuals of D. pentaphylla occur at higher altitudes, with $50 \%$ above $300 \mathrm{~m}$, whereas those of $D$. pinnata occur up to $200 \mathrm{~m}$. The median of $D$. pentaphylla altitude is greater than $D$. pinnata and the altitude median confidence intervals of two species do not overlap (figure 2).

The analysis by logistic regression revealed that the presence of $D$. pentaphylla (or absence of D. pinnata) is positively related to the latitude and altitude of occurrence (table 1). Longitude of occurrence, when added to the model, caused imprecision of partial coefficients of logistic regression (increasing the standard error), probably due to the great correlation of the longitude to the latitude $(r=0,842)$ (Zar 1996). When included in the model, grouped or as a unique independent variable, longitude contribution and that of other variables were not significant.

The altitude of specimens occurrence was not significant when analyzed as unique independent

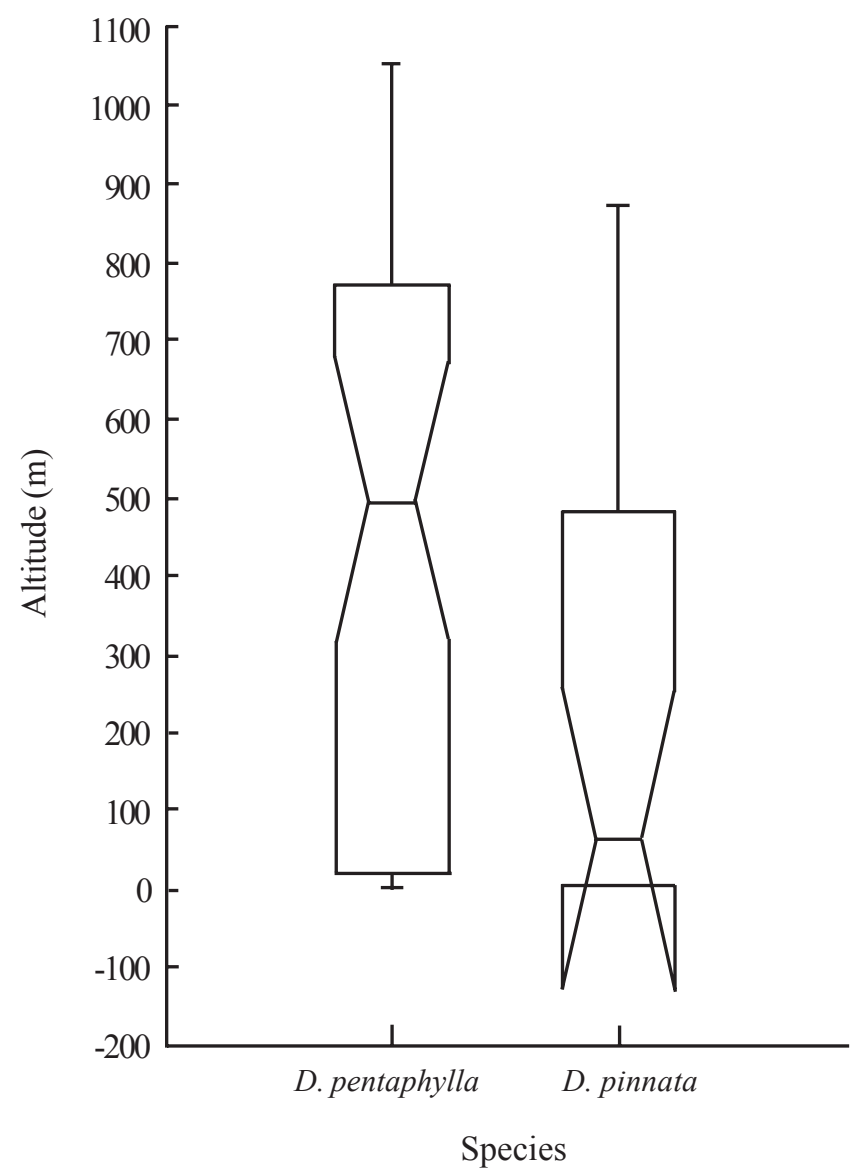

Figure 2. Box-plots of distribution per altitude for Dahlstedtia pinnata $(\mathrm{N}=15)$ and for $D$. pentaphylla $(\mathrm{N}=43)$. Rectangles delimitate $50 \%$ of observations and central traces represent the median. Bars indicate the total amplitude of distribution. Rectangle necks represent the 95\% confidence interval of median.

Table 1. Logistic regression of presence of $D$. pentaphylla (or absence of $D$. pinnata) (response-variable) and of latitude and altitude of occurrence (independent-variables). $\mathrm{N}=57$ localities. Log Likelihood $=-10.565, \mathrm{G}=44.573, \mathrm{p}=0.000$, d.f. $=2$; $\mathrm{R}_{\mathrm{L}}{ }_{\mathrm{L}}=0.678$; deciles of risk: Hosmer-Lemeshow $=5.347, \mathrm{p}=0.618$, d.f. $=7$; Pearson $=35.542, \mathrm{p}=0.975$, d.f. $=54$; deviance $=21.129$, $\mathrm{p}=1.000$, d.f. $=54$.

\begin{tabular}{lcccccrcr}
\hline Parameter & Estimate value & Standard error & $\mathrm{t}$ & $\mathrm{p}$ & \multicolumn{2}{c}{ Odds ratio and confidence interval (95\%) } \\
\cline { 3 - 7 } & & & & ratio & lower \\
\hline Constant & -115.568 & 37.325 & -3.096 & 0.002 & & 5.953 & 2803.288 \\
Latitude & 4.861 & 1.570 & 3.096 & 0.002 & 129.177 & 1.001 \\
Altitude & 0.006 & 0.002 & 2.571 & 0.010 & 1.006 & 1.011 \\
\hline
\end{tabular}


variable; however, the model including altitude and latitude fits better than the model including only latitude $\left(G=24.026 ; p<0.0001 ;\right.$ d.f. $\left.\left(\chi^{2}\right)=2\right)$. Such results indicate that latitude and altitude, when grouped, were important to explain the distribution of Dahlstedtia specimens, despite the low partial contribution of altitude (odds ratio $=1.006$; table 1 ).

Flowering and fruiting - Field studies revealed isolated plants occurring in moist habitats, inside the forest. Some individuals could be found in flower throughout the year when nearly two meters high. Individuals inside the forest showed a shorter flowering period than those found at the forest margin. Fruiting individuals were scarcely found in a six-year period of observations (1993-1995 and 1996-2000). They showed vegetative propagation (caulinar origin).

Experimental pollinations - D. pentaphylla $\times$ D. pinnata: pollen grains germinated on the stigma after $6 \mathrm{~h}$ (figure 3); pollen tubes reached the placenta after $24 \mathrm{~h}$, but did not fertilize the ovules; no dilated callose plugs were observed, nor was tube thickness irregular (figure 4); after $48 \mathrm{~h}$ pollen tubes were visible in the micropyle of the first and third ovules.

$D$. pinnata $\times D$. pentaphylla: pollen grains germinated on the stigma after $12 \mathrm{~h}$; after $24 \mathrm{~h}$ pollen tubes with dilated plugs were visible in the style and near the placenta; pollen tubes showed regular and irregular growth, with thickness variation (figures 5, 6). Some tubes reached the micropyle after $48 \mathrm{~h}$, but most of them did not penetrate the ovule, but rather presented an irregular trajectory (figures 7,8).

Pollen tubes penetrated the ovule through the micropyle, reached the nucellus and, soon afterwards, the embryo sac. Usually only one ovule in each ovary was fertilized. Fertilization was observed $48 \mathrm{~h}$ after interspecific pollination, evident by the presence of endospermic nuclei in division. The absence of fertilization was indicated by the presence of intact synergids and an organized embryo sac. Most of the ovules showed degeneration signs after $48 \mathrm{~h}$, characterized especially by the thickening of the outer periclinal wall of the nucellus cells and by compression of the inner integument. The non-fertilized embryo sac collapsed $96 \mathrm{~h}$ after pollination.

In $D$. pinnata $\times D$. pentaphylla an embryo mother cell was observed in an atypical micropylar place of the embryo sac, $96 \mathrm{~h}$ after pollination. In all analysed ovules of the crossings, a dense mucilaginous secretion filled the whole micropylar canal (figure 9). The mucilaginous nature of the secretion was evident by staining behaviour: material stained by Safranin after fixation with FAA presented pink coloration and flocculation, common when secretion is mucilaginous (O’Brien \& McCully 1981).

\section{Discussion}

Despite the similarity between species of Dahlstedtia in stem and root anatomy (Teixeira \& Gabrielli 2000), in embryogenesis (Teixeira et al. 2001) and in floral development (Teixeira \& Ranga, unpublished data), the present work confirms Burkart's position (1957) that Dahlstedtia comprises at least two species: $D$. pinnata and D. pentaphylla.

Dahlstedtia pentaphylla and D. pinnata show an allopatric distribution pattern, occurring in the coastal forest of Southeasthern and Southern Brazil. The presence of topographical barriers represented by the "Campos do Jordão", "Paraitinga" and "Juqueriquerê" Plateaus would have imposed a geographical isolation of the Dahlstedtia species in São Paulo State. The occurrence of $D$. pinnata on the western side of cited geographical barriers is probably due to an artificial introduction of this species at "Estação Biológica de Boracéia".

The Brazilian Atlantic coastal forests, according to the hypothesis of rain forest refugia, are considered to have been a refugium during the Pleistocene, which is suggested by studies on the distribution patterns of 127 species (Mori et al. 1981), endemism of Mouriri (Prance 1982) and occurrence of 940 endemic species of 1,288 listed by Gentry (1982) for this region. Preferential occurrence of Dahlstedtia species in the Atlantic coastal rain forest of Southeasthern and Southern Brazil may be attributed to the similarity in the physical characterization between the southeasthern and southern coast areas (see Bigarella et al. 1994). Nevertheless, climatic differences between Brazilian states exist. The climate of the northern coast of São Paulo State and of the coast of Rio de Janeiro State, according to FIBGE (1986) is characterized as Koeppen's Cfa - moist, hot summer (Koeppen 1948) whereas of the southern coast of São Paulo State and the coast of Paraná and Santa Catarina States as Koepen's Cfb - no dry period, warm summer (Koeppen 1948). Such differences can be related to the distribution pattern of the species, with $D$. pentaphylla occurring at higher latitudes than $D$. pinnata, as indicated by geographical distribution and logistic regression. Distribution per altitude showed that both species are found at high and low altitudes; however, the greatest number of $D$. pentaphylla individuals was registered 

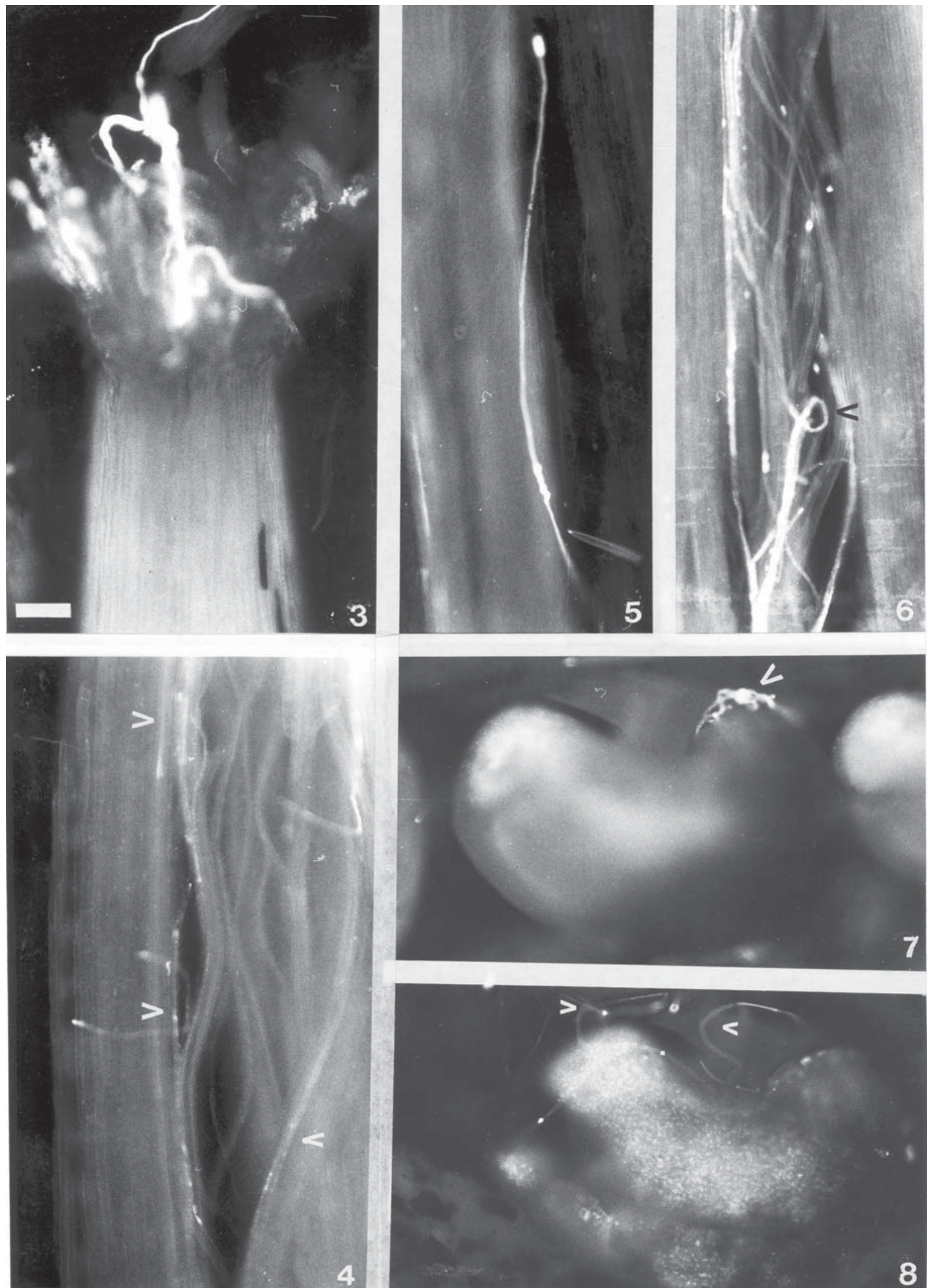

Figures 3-8. Pollen grain germination and pollen tube growth. 3-4. Dahlstedtia pentaphylla $\times$ D. pinnata. 3. Pollen grain germinating on the stigma. 4. Pollen tubes in the style (arrows). 5-8. D. pinnata $\times$ D. pentaphylla. 5. Irregular thickened pollen tube inside the style. 6. Irregular growth of pollen tube (arrow). 7. Pollen tubes into the micropyle (arrow). 8. Pollen tubes around the ovule (arrows). Bar $=70 \mu \mathrm{m}$. 


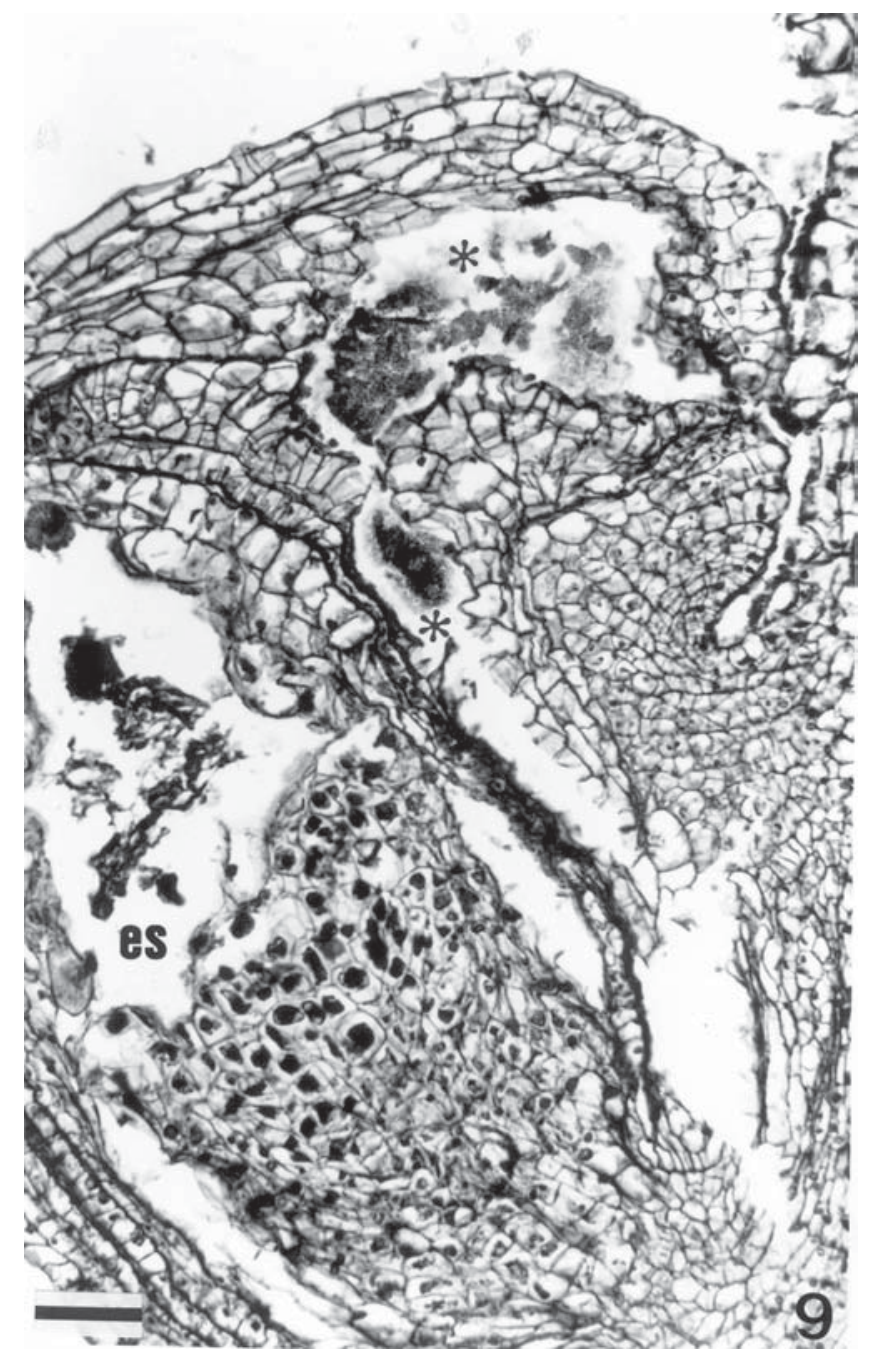

Figure 9. Longitudinal section of an unfertilized ovule $96 \mathrm{~h}$ after pollination of Dahlstedtia pinnata $\times D$. pentaphylla. Note the mucilaginous secretion (*) filling all micropylar canal and the region near the embryo sac (es). Bar $=43 \mu \mathrm{m}$.

at high altitudes. Therefore, altitude may also have an effect on the pattern of distribution of the species.

No studies on the pollinators of Dahlstedtia species have been published. Sousa \& Sousa (1981), based on floral morphology, suggested that the species are ornithophilous. S. Buzato (unpublished data) observed a female hummingbird (Ramphodon naevius Phaetorninae) visiting flowers of $D$. pinnata, in Picinguaba. Individuals of this long-beaked hummingbird species are territorial and occur in the interior of undisturbed forests. They visit flowers at constant intervals and are looking for high reward nectar, $i$. e., for higher concentration and lower volume of nectar (A. Araújo, unpublished data). The territorial behavior of this hummingbird certainly limits pollen dispersal and, consequently, pollination between neighbouring individuals is favored (Proctor et al. 1996). If D. pinnata and D. pentaphylla are preferentially pollinated by territorial hummingbirds like Ramphodon naevius, and their territories are really small, pollen flow between geographically disjunct species would not occur.

Species are intersterile, since although pollen tubes were observed at the micropylar entrance after $48 \mathrm{~h}$, no proembryos were formed from interspecific crosses, but rather between 72 and $96 \mathrm{~h}$ after pollination, ovules began to degenerate. Teixeira et al. (2001), working on the same individuals of Dahlstedtia, found that both species are self-compatible, with seemingly normal germination of self pollen grains on the stigmatic surface, in the morphology of the pollen tubes growing in the stylar and placental tissues, and in the embryogenesis. Moreover, the micropylar secretion observed by ourselves following interspecific crosses was greater than that observed by Texeira et al. (2001) following their intraspecific crosses, suggesting that this secretion may act as a barrier to the pollen tube entrance. Such observation indicates a mechanism preventing gene flow between the two species.

A difference in the pollen tube growth was observed in interspecific crossings, depending on the pollen donor. Pollen tube growth into the style and placenta was regular in $D$. pentaphylla $\times D$. pinnata, but irregular in $D$. pinnata $\times D$. pentaphylla, suggesting that D. pinnata has developed some characteristics of style specifity.

In conclusion, D. pentaphylla and D. pinnata are geographically isolated, although they flower more or less synchronously. Experimental pollinations show the two species to be intersterile. These species therefore conform well to Mayr's (1992) biological species concept, which defines species as interbreeding communities that are reproductively isolated from one another. Experimental work on natural populations of Dahlstedtia species indicates that a prezygotic isolating mechanism is acting, besides the occurrence of external barriers to gene flow, $i$. e., the two species with a somewhat controversial history do in fact exist.

Acknowledgements - We thank to Eduardo L. Borba, Peter Gibbs, Rodrigo A. Santinelo Pereira and Volker Bittrich for many helpful comments and to Iara Bressan for the technical assistance. The first author thanks to Fapesp (process number 97/11242-0) for the financial support.

\section{References}

BENTHAM, G. 1862. Leguminosae. In Flora Brasiliensis (C.F.P Martius, ed.). Frid. Fleischer, Lipsiae, v.15, pars 1, p.1-332. 
BIGARELLA, J.J., BECKER R.D. \& SANTOS G.F. 1994. Estrutura e origem das paisagens tropicais e subtropicais, v.1. Daufsc, Florianópolis.

BURKART, A. 1957. Dahlstedtia pentaphylla (Taub.) Burkart, nov. comb. Darwiniana 11:269.

FIBGE. 1986. Atlas Geográfico. $3^{\mathrm{a}}$ ed. Fundação Instituto Brasileiro de Geografia e Estatística, Rio de Janeiro.

GEESINK, R. 1981. Tephrosieae (Benth.) Huch. In Advances in Legume Systematics (R.M. Polhill \& P.H. Raven, eds.). Royal Botanic Gardens, Kew, v.1, p.245-260.

GEESINK, R. 1984. Scala Millettiearum. A survey of the genera of the tribe Millettieae (Leguminosae, Papilionoideae). E.J. Brill / Leiden University Press, Leiden.

GENTRY, A.H. 1982. Neotropical floristic diversity: phytogeographical connections between Central and South America, Pleistocene climatic fluctuations, or an accident of the Andean orogeny? Annals of the Missouri Botanical Garden 69:557-593.

HOSMER, D.W. \& LEMESHOW, S. 1989. Applied logistic regression. John Wiley, New York.

HUTCHINSON, J. 1964. The genera of flowering plants (Angiospermae) - Dicotyledons, v.1. Clarendon Press, Oxford.

KARNOVSKY, M.J. 1965. A formaldehyde-glutaraldehyde fixative of high osmalarity for use in eletron microscopy. Journal of Cell Biology 27:137A-138A.

KOEPPEN, W. 1948. Climatología. Fondo de Cultura Econômica, Mexico.

MALME, G. 1905. Dahlstedtia, eine neue Leguminosen Gattung. Arkiv för Botanik 4:1-7.

MARTIN, F.N. 1959. Staining and observing pollen tubes in the style by means of fluorescence. Stain Technology $34: 125-128$.
MAYR, E. 1992. A local flora and the biological species concept. American Journal of Botany 79:222-238.

MORI, S.A., BOOM, B.M. \& PRANCE, G.T. 1981. Distribution patterns and conservation of Eastern Brazilian Coastal Forest tree species. Brittonia 33:233-245.

O'BRIEN, T.P. \& MCCULLY, M.E. 1981. The study of plant structure: principles and selected methods. Termorcarphi PTY, Melbourne.

PRAKASH, N. 1986. Methods in plant microtechnique. $2^{\text {nd }}$ ed. The University of New England, Armidale.

PRANCE, G.T. 1982. A review of the phytogeographic evidences for Pleistocene climate changes in the Neotropics. Annals of the Missouri Botanical Garden 69:594-624.

PROCTOR, M., YEO, P. \& LACK, A. 1996. The natural history of pollination. Harper Collins Publishers, London.

SOUSA, M. \& SOUSA, M.P. 1981. New World Lonchocarpinae. In Advances in Legume Systematics (R.M. Polhill \& P.H. Raven, eds.). Royal Botanic Gardens, Kew, v.1, p.261-281.

TAUBERT, P.H.W. 1889. Camptosema ?pentaphyllum Taub. Flora 47:428.

TEIXEIRA, S.P. \& GABRIELLI, A.C. 2000. Anatomia do eixo vegetativo de Dahlstedtia pinnata (Benth.) Malme e D. pentaphylla (Taub.) Burkart (Leguminosae, Papilionoideae). Revista Brasileira de Botânica 23:1-11.

TEIXEIRA, S.P., PRAKASH, N. \& RANGA, N.T. 2001. Ovule and early seed development related to seed abortion in Dahlstedtia pinnata and D. pentaphylla (Leguminosae, Papilionoideae). Phytomorphology 51:41-50.

VANNI, R.O. \& RODRÍGUEZ, M. 1999. Dahlstedtia (Leguminosae, Millettieae) nueva cita para la flora argentina. Hickenia 3:5-8.

ZAR, J.H. 1996. Biostatistical analysis, $3^{\text {rd }}$ ed. Prentice Hall, New Jersey. 